\title{
PENGARUH INTELEGENCE QUOTIENT (IQ), EMOTIONAL QUOTIENT (EQ), DAN SPIRITUAL QUOTIENT (SQ) TERHADAP PEMAHAMAN AKUNTANSI SISWA DI SMK SUMPAH PEMUDA 2
}

\section{THE INFLUENCE OF INTELEGENCE QUOTIENT ( IQ), EMOTIONAL QUOTIENT (EQ), AND SPIRITUAL QUOTIENT ( SQ) TOWARD UNDERSTANDING IN ACCOUNTING LESSON OF ACCOUNTANCY STUDENTS IN SMK SUMPAH PEMUDA 2}

\author{
I.C. Kusuma, L.S.M. Rizki \\ Program Studi Akuntansi Fakultas Ekonomi Universitas Djuanda Bogor \\ Jl. Tol Ciawi No. 1, Kotak Pos 35, Kode Pos 16720, Telp/Fax : (0251) 8245155 \\ Email : indra.Cahya.kusuma@unida.ac.id, selody.sl@gmail.com
}

\begin{abstract}
This research is replicated from Rahman (2014) and Pasek (2015). This research aim to examine impact of Intelectual Quotient, Emotional Quotient, and Spritual Quotient to wards Understanding of Accountancy. This study used a survey method that uses primary data collected from questionnaires. The population in this study were student of the Concentration of Accounting at SMK Sumpah Pemuda 2 Ciawi. The member of sample taken in this study are 31 student XII Classi. Hypotesis tets use liniear coreelation and regression. Result of the hypothesis test indicate that Intelectual Quotient, Emitional Quotient, and Spiritual Quotient has positive correlation with understanding of Accountancy. The result showed simulataneous Intelectual Quotient, Emotional Quotient, and Spiritual Quotient has significantly impact toward Understanding of Accountancy. In parcial Intelectual Quotient has a Positive and significant impact towards Understanding of Accountancy, meanwhile Emotional Quotient and Spiritual Quotient has not impact towards Understanding of Accountancy.
\end{abstract}

Key word: Intelectual Quotient (IQ), Emotional Quotient (EQ), Spiritual Quotient (SQ), and Understanding of Accountancy.

\begin{abstract}
ABSTRAK
Penelitian ini merupakan repilikasi dari penelitian rahman (2014) dan pasek (2015). Tujuan penelitian ini untuk menguji pengaruh kecerdasan intelectual, kecerdasan emosional, dan kecerdasan spiritual terhadap pemahaman akuntansi. Penelitian ini menggunakan metode suvei yang menggunakan data primer yang didapat dari kuesioner. Populasi dalam penelitian ini adalah seluruh siswa Jurusan Akuntansi di SMK Sumpah Pemuda 2 Ciawi. Jumlah sampel yang diambil 31 siswa jurusan Akuntansi Kelas XII. Uji hipotesis menggunakan korelasi dan regresi linear. Tes menunjukan bahwa Intellectual Quotient, Emotional Quotient, dan Spiritual Quotient berkorelasi positif dengan Pemahaman Akuntansi. Hasil analisis data menunjukan secara serempak Intellectual Quotient, Emotional Quotient, dan Spiritual Quotient berpengaruh signifikan terhadap Pemahaman Akuntansi. Secara parsial Intellectual Quotient memiliki pengaruh positif dan signifikan terhadap Pemahaman Akuntansi, sedangkan Emotional Quotient dan Spiritual Quotien tidak memiliki pengaruh.
\end{abstract}

Kata kunci: Intelegent Quotient (IQ), Emotional Quotient (EQ), Spiritual Quotient, dan Pemahaman Akuntansi. 


\section{PENDAHULUAN}

Pendidikan akuntansi yang diselenggarakan oleh sekolah menengah kejuruan ditujukan untuk mendidik siswa agar siap bekerja dibidang akunting.sudem dalam rahmi (2010), kecemasan akan ketidakjelasan terhadap pemahaman akuntansi yang dihasilkan oleh sekolah menengah kejuruan, hal ini dampak dari banyaknya sekolah yang belum mampu mendidik murid-muridnya menguasai dengan baik ilmu pengetahuan serta keterampilan hidip khususnya untuk bidang akuntansi. Banyak hal harus diperhatikan dalam dunia pendidikan untuk menciptakan siswa yang berkualitas yang dapat memahami pelajaran, khususnya terhadap pemahaman akuntansi. Konsentrasi belajar sangat diperlukan agar siswa dapat mefokuskan dirinya terhadap pelajaran khususnya akuntansi.

Akuntansi merupakan pengetahuaan yang harus dipahami oleh murid jurusan akuntansi di sekolah. Akuntansi terbagi menjadi beberapa mata pelajaran seperti siklus akuntansi, akuntansi keuangan, akuntansi pajak, akuntansi biaya, aplikasi komputer akuntansi, dan siklus akuntansi manufaktur. Ketelitian, kesabaran, dan keterampilan dalam menghitung sangat diperluakan siswa dalam menguasai akuntansi. Menurut rahmi (2013), proses pemahaman dalam bidang studi akuntansi ini dipengaruhi oleh Quotient yang dimiliki siswa, baik Inttelegence Quotient (IQ), Emotional Quotient (EQ), maupun Spiritual Quotient (SQ). Pada saat ini banyak program pendidikan yang hanya terfokus pada kecerdasal akal (IQ), sementara itu yang diperlukan ialah bagaimana cara mengembangkan kecerdasan hati, seperti ketangguhan, optimisme, inisiatif, dan kemampuan beradaptasi. Hal-hal tersebut sekarang menjadi dasar penilaian. Keseimbangan antara IQ, EQ, dan SQ adalah kunci keberhasilan belasar siswa di sekolah.

Penelitian ini dilaksanakan pada siswa jurusan Akuntansi di SMK Sumpah pemuda 2. Masalah didalam penelitian ini adakah kurangnya penjelasan materi di kelas, sikap cuek dengan situasi kelas, tidak memperhatikan tugas yang diberikan, dan menutunnya prestasi siswa. Rata-rata nilai UTS Mata Pelajaran Produktif Akuntansi dan rata-rata jumlah kehadiran siswa akuntansi siswa kelas XII pada saat berada di Kelas X dan Kelas XII, dapat dilihat pada table berikut ini :

Tabel 1. Rata-rata UTS Mata Pelajaran Produktif Akuntansi dan Rata-rata Kehadiaran Siswa Jurusan Akuntansi Tahun Ajaran 2015/2017 SMK Sumpah Pemuda2

\begin{tabular}{lll}
\hline \multirow{2}{*}{ Kelas } & $\begin{array}{l}\text { Rata-rata Nilai UTS } \\
\text { Mata Pelajaran Produktif Akuntansi }\end{array}$ & $\begin{array}{l}\text { Rata-rata } \\
\text { Kehadiran }\end{array}$ \\
\hline X & 79,80 & $95,35 \%$ \\
XI & 80,00 & $97,37 \%$ \\
XII & 81,30 & $94,44 \%$ \\
\hline
\end{tabular}

Sumber : Buku Induk SMK Sumpah Pemuda 2

Berdasarkan table 1 diatas rata-rata nilai

UTS Mata Pelajaran produkrif Akuntansi terendah terdapat pada saat Kelas $\mathrm{X}$ dengan rata-rata nilai 79,80 . Nilai tertinggi terdapat saat Kelas XII dengan rata-rata nilai 81,30, sedamgkan nilai saat berada di Kelas XI menmpunyai nilai rata-rata 80,00. Hal ini tidak seperti harap guru di sekolah SMK Sumpah Pemuda2 yang mengharapkan nilai rata-rata kelas diatasa 85,00. Berdasarkann tabel 1 diatas juga dapat dilihat jumal rata-rata kehadiran siswa jurusan Akuntansi pada saat Kelas X 95,35\% per pertemuan, jumlah kehadiaran pada saat di Kelas XI sebesar $97,37 \%$ pertemuan, dan jumalah rata-rat kehadiran saat di Kelas XII sebesar 94,44\% per pertemuan. Hal ini menunjukan tingkat kehadiran siswa sudah baik.

Berdasarkan uraian tersebut diatas peneliti tertarik meneliti faktor apa yang mempengaruhi prestasi murid dalam hal ini diwakili oleh pemahaman dalam bidang akuntansi, selain jumlah absensi. Peneliti tertarik untuk melaksanakan penelitian dengan judul " pengaruh Intellegence Quotien (IQ), Emotional Quotien (EQ), dan Spiritual Quotien (SQ) Terhadap Pemahaman Akuntansi Pada Siswa SMK Sumpah Pemuda 2.

Akuntansi adalah seni dari pencatatan, penggolaongan dan peringkasan daripada peristiwa-peristiwa dan kejadian-kejadian yang setidak-tidaknya sebagian bersifat 
keuangan denga tepat dan dinyatakan dalam uang, serta penafsiran berdasarkan pencatatan tersebut. (Munaawir, 2002:15). Menurut Kieso (2002:2), akuntansi dapat dijelaskan secara tepat dengan menjelaskan tiga karakteristik dari akuntansi : pengidentifikasian, pengukuran, dan pengomunikasian informasi keuangan tentang entitas ekonomi kepada pemakai yang berkepentingan.

Menurut siegel dalam Lubis, dkk. (2010), Akuntansi keperilakuan adalah bagian akuntansi yang mempelajari hubungan perilaku manusia dengan sistem. Istilah sistem dalam akuntansi ialah seluruh desain alat pengendalian manajemen meliputi sistem pengendalian, sistem penganggaran, desain akuntansi pertanggungjawaban, desain organisasi seperti tidak terpusat atau terpusat, desai pengumpulan biaya, desain penilaian kinerja serta pelaporan keuangan.

Pemahaman akuntansi menurut Mawardi (2011) terdapat tiga konsep dasar unsur utama yaitu aktiva, hutang, dan modal. Dalam pengertian aktiva tidak sebatas pada kekayaan perusahaan yang berwujud saja, tetapi biaya yang masih harus dialokasikan juga termasuk pengahasilan yang akan datang, serta yang tidak berwujud. Pemahaman akuntansi merupakan sejauh mana kemampuan untuk memahai akuntansi baik sebagai perangkat pengetahuan maupun sebagai praktik.

Kecerdasan Intelektual (IQ) merupakan pengelompokan kecerdasan manusia yang didominasi oleh kemampuan daya pikir rasional dan logika. Lebih kurang 80\%, IQ diturunkan dari orang tua, sedangkan selebihnya dibangun pada usia sangan dini yaitu 0-2 tahun kehidupan manusia yang pertam. Sifatnya relatif digunkan sebagai prediktor keberhasilan individu dimasa depan. Implikasinya, sejumlah riset untuk menemukan alat tes (tes IQ) dirancang sebagai tiket untuk memasuki dunia pendidikan sekaligus dunia kerja (Amran, 2009:62).

Pengetian Kecerdasan Emosional menurut Goleman (2005: 18) kemampuan akademik bawaan, nilai rapor, dan pendidikan tinggi tidak memprediksi seberapa baik kinerja seseorang yang sudah bekerja atau seberapa tinggi kesuksesan yang dicapai dalam hidup.

Kecerdasan Spiritual yang ditemukan oleh Zohar dan Marshall (2007:36) menegaskan bahwa kecerdasan spiritual adalah landasan untuk membangun kecerdasan intelektual dan emosional. Rachmi (2010:71) menjelaskan kecerdasan spiritual sebagai pikiran yang memiliki inspirasi, dan penghayatan ketuhanan.

Siegel dalam Lubis, dkk. (2010), Akuntansi keperilakuan (behavioral accounting) adalah cabang akuntansi yang mempelajari hubungan antara perilaku manusia dengan sistem. Istilah sistem akuntansi yang dimaksud di sini dalam arti yang luas yang meliputi seluruh desain alat pengendalian manajemen yang meliputi sistem pengendalian, sistem penganggaran, desain akuntansi pertangungjawaban, desain organisasi seperti desentralisasi atau sentralisasi, desain pengumpulan biaya, desain penilaian kinerja serta pelaporan keuangan. Secara lebih terinci ruang lingkup akuntansi keperilakuan meliputi:

1) Mempelajari pengaruh antara perilaku manusia terhadap desain, konstruksi, dan penggunaan sistem akuntansi yang diterapkan dalam perusahaan, yang berarti bagaimana sikap dan gaya kepemimpinan manajemen mempengaruhi sifat pengendalian akuntansi dan desain organisasi;

2) Mempelajari pengaruh sistem akuntansi terhadap perilaku manusia, yang berarti bagaimana sistem akuntansi mempengaruhi motivasi, produktivitas, pengambilan keputusan, kepuasan kerja dan kerja sama;

3) Metode untuk memprediksi perilaku manusia dan strategi untuk mengubahnya, yang berarti bagaimana sistem akuntansi dapat dipergunakan untuk mempengaruhi perilaku.

Sebagai bagian dari ilmu keperilakuan (behavioral science), teori-teori akuntansi keperilakuan dikembangkan dari penelitian empiris atas perilaku manusia diorganisasi. Dengan demikian, peranan penelitian dalam pengembangan ilmu itu sendiri sudah tidak diragukan lagi. Ruang lingkup penelitian di bidang akuntansi keperilakuan sangat luas sekali, tidak hanya meliputi bidang akuntansi manajemen saja, tetapi juga menyangkut penelitian dalam bidang etika, auditing (pemeriksaan akuntan), sistem informasi akuntansi bahkan juga akuntansi keuangan.

Kamus Besar Bahasa Indonesia (2010: 74), pemahaman berasal dari kata paham yang 
artinya pengertian; pengetahuan yang banyak. Jika mendapat imbuhan pe-an menjadi pemahaman, artinya (1) proses, (2) perbuatan, (3) cara memahami atau memahamkan (mempelajari baik-baik supaya paham). Sehingga dapat diartikan bahwa pemahaman adalah suatu proses, dan cara mempelajari baik-baik supaya paham dan pengetahuan banyak. Panangian (2012) menyatakan bahwa pemahaman bukan kegiatan berpikir semata, melainkan pemindahan letak dari dalam berdiri disituasi atau dunia orang lain. Mengalami kembali situasi yang dijumpai pribadi lain didalam (sumber pengetahuan tentang hidup, kegiatan melakukan pengalaman pikiran), pengalaman yang terhayati. Pemahaman merupakan suatu kegiatan berpikir secara diam-diam, menemukan dirinya dalam orang lain.

Sudaryono (2012: 44), pemahaman adalah hasil belajar, misalnya peserta didik dapat menjelaskan dengan susunan kalimatnya sendiri atas apa yang dibacanya atau didengarnya, memberi contoh lain dari yang telah dicontohkan guru dan menggunakan petunjuk penerapan pada kasus lain. Pemahaman adalah kemampuan seseorang untuk menangkap makna dan arti dari bahan yang dipelajari, yang dinyatakan dengan menguraikan isi pokok dari suatu bacaan atau mengubah data yang disajikan dalam bentuk tertentu ke bentuk yang lain. Sudijono (2009: 50) mengatakan bahwa pemahaman (Comprehension) adalah kemampuan seseorang untuk mengerti atau memahami sesuatu setelah sesuatu itu diketahui dan diingat. Dengan kata lain, memahami adalah mengerti tentang sesuatu dan dapat melihatnya dari berbagai segi. Dengan demikian jelaslah, bahwa comprehension atau pemahaman merupakan unsur psikologi yang sangat penting dalam belajar.

Mawardi (2011), pemahaman akuntansi terdiri dari tiga konsep dasar bagian utama yaitu aktiva, hutang dan modal. Dalam pengertian aktiva tidak terbatas pada kekayaan perusahaan yang berwujud saja, tetapi juga termasuk pengeluaran-pengeluaran yang belum dialokasikan (deffered changes) atau biaya yang masih harus dialokasikan pada penghasilan yang akan datang, serta aktiva yang tidak berwujud lainnya (intangible asset) misalnya goodwill, hak paten, hak menerbitkan dan sebagainya. Pemahaman akuntansi merupakan sejauh mana kemampuan untuk memahami akuntansi baik sebagai seperangkat pengetahuan (body of knowledge) maupun sebagai proses atau praktik.

Penguasaan pengetahuan atau keterampilan yang dikembangkan oleh mata pelajaran, lazimnya ditunjukkan dengan nilai tes atau angka yang diberikan oleh pengajar. Suwardjono (2005: 4) menyebutkan pengetahuan akuntansi dapat dipandang dari dua sisi pengertian yaitu sebagai pengetahuan profesi (keahlian) yang dipraktekkan di dunia nyata dan sekaligus sebagai suatu disiplin pengetahuan yang diajarkan. Akuntansi sebagai objek pengetahuan, akademisi memandang akuntansi sebagai dua bidang kajian yaitu bidang praktek dan teori. Teori akuntansi tidak lepas dari praktik akuntansi karena tujuan utamanya adalah menjelaskan praktik akuntansi berjalan dan memberikan dasar bagi pengembangan praktik. Akuntansi cenderung dikembangkan atas dasar pertimbangan nilai (value judgment), yang dipenuhi oleh faktor lingkungan tempat akuntansi dipraktikkan. Belkaoli (2000) menjelaskan bahwa proses penyusunan teori akuntansi sebaiknya dilengkapi pula dengan proses pembuktian (verification) dan pengesahan (validation) teori.

Prinsip akuntansi merupakan suatu pedoman dalam menyusun laporan keuangan yang secara umum dapat diterima oleh semua pihak. Dalam praktik-praktik bisnis biasanya sering dijumpai bahwa laporan keuangan harus disusun dan disajikan sesuai dengan prinsip akuntansi berterima umum (PABU), atau di Amerika Serikat disebut dengan GAAP (Generally Accepted Accounting Principles). Bidang teori berkepentingan dengan penjelasan, deskripsi, dan argumen yang dianggap melandasi praktek akuntansi yang semuanya dicakup dalam suatu pengetahuan yang disebut teori akuntansi. Secara umum, fungsi utama teori akuntansi adalah untuk memberikan kerangka pengembangan ide-ide baru dan membantu proses pemilihan akuntansi (Mathews dan Parera, 1993).

Tolak ukur pemahaman akuntansi dalam penelitian ini akan diukur dengan menggunakan nilai mata diklat kompetensi kejuruan akuntansi, yaitu:

a. Siklus akuntansi, termasuk didalamnya mengelola dokumen transaksi, memposes 
entri jurnal, memproses buku besar, dan menyusun laporan keuangan.

b. Akuntansi keuangan, termasuk didalamnya memproses dokumen dana kas kecil, memproses dana kas di bank, mengelola kartu piutang, mengelola kartu persediaan, mengelola kartu aktiva tetap, dan mengelola kartu utang.

c. Akuntansi pajak, yaitu menyiapkan surat pemberitahuan pajak.

d. Akuntansi biaya, yaitu menyajikan laporan harga pokok produk.

e. Aplikasi komputer akuntansi.

f. Siklus akuntansi manufaktur.

Kecerdasan intelektual (IQ) merupakan pengkualifikasian kecerdasan manusia yang didominasi oleh kemampuan daya pikir rasional dan logika. Lebih kurang 80\%, IQ diturunkan dari orangtua, sedangkan selebihnya dibangun pada usia sangat dini yaitu 0-2 tahun kehidupan manusia yang pertama. Sifatnya relatif digunakan sebagai prediktor keberhasilan individu dimasa depan. Implikasinya, sejumlah riset untuk menemukan alat (tes IQ) dirancang sebagai tiket untuk memasuki dunia pendidikan sekaligus dunia kerja (Amran, 2009: 62).

Dwijayanti (2009: 24) menyebutkan kecerdasan intelektual sebagai suatu kemampuan yang terdiri dari tiga ciri yaitu: a) Kemampuan untuk mengarahkan pikiran atau mengarahkan tindakan. b) Kemampuan untuk mengubah arah tindakan bila tindakan itu telah dilakukan. c) Kemampuan untuk mengkritik diri sendiri. Robins dan Judge (2008: 57) mengatakan bahwa kecerdasan intelektual adalah kemampuan yang di butuhkan untuk melakukan berbagai aktivitas mental berpikir, menalar dan memecahkan masalah.

Yani (2011) mengatakan bahwa kecerdasan intelektual adalah kemampuan untuk memperoleh, memanggil kembali (recall), dan menggunakan pengetahuan untuk memahami konsep-konsep abstrak maupun konkret dan hubungan antara objek dan ide, serta menerapkan pengetahuan secara tepat. Kecerdasan intelektual menurut Sternberg (2008: 121) adalah sebagai kemampuan untuk belajar dari pengalaman, berfikir menggunakan proses-proses metakognitif, dan kemampuan untuk beradaptasi dengan lingkungan sekitar.

Kecerdasan intelektual merupakan kemampuan menganalisis, logika dan rasio seseorang. Dengan demikian, hal ini berkaitan dengan keterampilan bicara, kecerdasan akan ruang, kesadaran akan sesuatu yg tampak, dan penguasaan matematika. IQ mengukur kecepatan kita untuk mempelajari hal-hal baru, memusatkan perhatian pada aneka tugas dan latihan, menyimpan dan mengingat kembali informasi objektif, terlibat dalam proses berfikir, bekerja dengan angka, berpikir abstrak dan analitis, serta memecahkan masalah dan menerapkan pengetahuan yg telah ada sebelumnya. (Anastasi, 2007: 220).

Goleman (2005: 18) menyatakan bahwa kemampuan akademik bawaan, nilai rapor, dan prediksi kelulusan pendidikan tinggi tidak memprediksi seberapa baik kinerja seseorang sudah bekerja atau sebarapa tinggi sukses yang dicapainya dalam hidup. Goleman (2005: 26) menyatakan bahwa seperangkat kecakapan khusus seperti empati, disiplin diri, dan inisiatif mampu membedakan orang sukses dari mereka yang berprestasi biasa-biasa saja, selain kecerdasan akal yang mempengaruhi keberhasilan orang dalam bekerja. Goleman (2005: 43) mendefinisikan kecerdasan emosional adalah kemampuan mengenali perasaan diri sendiri dan perasaan orang lain, memotivasi diri sendiri, serta mengelola emosi dengan baik pada diri sendiri dan dalam hubungan dengan orang lain.

Rachmi (2010: 31) mendefinisikan kecerdasan emosional sebagai kemampuan merasakan, memahami, dan secara efektif menerapkan daya dan kepekaan emosi sebagai sumber energi, informasi, koneksi dan pengaruh yang manusiawi. Kecerdasan emosi menuntut seseorang untuk belajar mengakui, menghargai perasaan diri sendiri dan orang lain serta menanggapinya dengan tepat dan menerapkan secara efektif energi emosi dalam kehidupan sehari-hari.

\section{Melandy dan Aziza (2006:42)} menyatakan bahwa, kecerdasan emosional adalah kecerdasan untuk menggunakan emosi sesuai dengan keinginan, kemampuan untuk mengendalikan emosi sehingga memberikan dampak yang positif. Kecerdasan emosional dapat membantu membangun hubungan dalam menuju kebahagiaan dan kesejahteraan. Rachmi (2010: 61) 
mendefinisikan kecerdasan emosional sebagai komponen yang membuat seseorang menjadi pintar menggunakan emosinya. Emosi manusia berada di wilayah dari perasaan lubuk hati, naluri yang tersembunyi dan sensasi emosi yang apabila diakui dan dihormati, kecerdasan emosional akan menyediakan pemahaman yang lebih mendalam dan lebih utuh tentang diri sendiri dan orang lain. Melandy dan Aziza (2006: 44) mendefinisikan kecerdasan emosional adalah kemampuan untuk mengenali perasaan, meraih dan membangkitkan perasaan untuk membantu pikiran, memahami perasaan dan maknanya, dan mengendalikan perasaan secara mendalam sehingga membantu perkembangan emosi.

Kecerdasan spiritual ditemukan oleh Zohar dan Marshall pada pertengahan tahun 2000. Zohar dan Marshall (2007: 36) menegaskan bahwa kecerdasan spiritual adalah landasan untuk membangun kecerdasan intelektual dan kecerdasan spiritual. Rachmi (2010: 71) mendefinisikan kecerdasan spiritual sebagai pikiran yang mendapat inspirasi, dorongan, efektivitas yang terinspirasi, dan penghayatan ketuhanan yang semua manusia menjadi bagian didalamnya.

Rachmi (2010: 78) menyebutkan kecerdasan spiritual sebagai fakultas dimensi non-material atau jiwa manusia. Kecerdasan spiritual sebagai intan yang belum terasah dan dimiliki oleh setiap insan. Manusia harus mengenali seperti adanya lalu menggosoknya sehingga mengkilap dengan tekad yang besar, menggunakannya menuju kearifan, dan untuk mencapai kebahagiaan yang abadi.

Wahab dan Umiarso (2011: 52) menyatakan kecerdasan spritual adalah kecerdasan yang sudah ada dalam setiap manusia sejak lahir yang membuat manusia menjalani hidup penuh makna, selalu mendengarkan suara hati nuraninya, tak pernah merasa sia-sia, semua yang dijalaninya selalu bernilai.

Ludigdo dkk (2006: 41) menyatakan bahwa Kecerdasan spiritual adalah kecerdasan untuk menghadapi dan memecahkan persoalan makna dan nilai, yaitu menempatkan perilaku dan hidup manusia dalam konteks makna yang lebih luas dan kaya, serta menilai bahwa tindakan atau hidup seseorang lebih bermakna dibandingkan dengan yang lain. Kecerdasan spiritual tidak mesti berhubungan dengan agama. Kecerdasan spiritual mendahului seluruh nilai spesifik dan budaya manapun, serta mendahului bentuk ekspresi agama manapun yang pernah ada. Namun, bagi sebagian orang mungkin menemukan cara pengungkapan kecerdasan spiritual melalui agama formal sehingga membuat agama menjadi perlu.

Ginanjar (2005: 41) mendefinisikan kecerdasan spiritual sebagai kemampuan untuk memberi makna ibadah terhadap setiap perilaku dan kegiatan melalui langkah-langkah dan pemikiran yang bersifat fitrah, menuju manusia yang seutuhnya dan memiliki pola pemikiran integralistik, serta berprinsip hanya karena Allah. Ginanjar (2005: 47) menyebutkan kecerdasan Spiritual adalah kemampuan untuk memberi makna spiritual terhadap pemikiran, perilaku dan kegiatan, serta mampu menyinergikan IQ, EQ dan SQ secara komprehensif.

\section{METODE PENELITIAN}

Objek penelitian ini adalah siswa siswi SMK Sumpah Pemuda 2. Lokasi penelitian ini adalah SMK Sumpah Pemuda 2 yang terletak di Kp. Cukanggaleuh RT. 02 RW. 05 Desa jambuluwuk Kecamatan Ciawi Kabupaten Bogor Pos 16760.

Desain penelitian ini ialah kualitatif yang dikuantitatifkan bersifat asosiatif kausal, yaitu dengan menekankan pada segi pengukuran variabel dengan menggunakan teknik dan alat ukur yang obyektif, yang bertujuan untuk mencaritau hubungan antara dua variabel atau lebih., dengan penelitian ini maka akan dapan dibangun suatu teori yang dapat berfungsi untuk menjelaskan, meramalkan dan mengontrol suatu gejala.

Untuk memudahkan proses analisa, maka penulis mengklasifikasikan variabel penelitian sebagai berikut:

1. Veriabel independen adalah variabel yang mempengaruhi kepada dependen. Dalam penelitian ini variabel independen adalah IQ (Intellegency Quotien), EQ (Emotional Quotien), dan SQ (Spiritual Quotien).

2. Variabel dependen adalah varibel yang dapat dipengaruhi oleh variabel independen. Dalam skripsi ini varibel dependen ialah pemahaman akuntansi.

Populiasi dalam penelitian ini adalah siswa/i jurusan Akuntansi di SMK Sumpah Pemuda 2 Ciawi dengan jumlah 112. Sampel akan diambil menggunakan metode penarikan 
sampel purposive sample,dimana populasi yang akan dijadikan sampel penelitian adalah populasi yang memenuhi kriteria sampel tertentu yaitu siswa/i kls XII Jurusan Akuntansi yang masih aktif sebagai siswa, maka sampel dalam penlitian ini berjumlah 31 siswa. Metode yang digunakan untuk mengumpulakan data adalah dengan cara menyebarkan kuesioner kepada seluruh sampel penelitian. Analisis data didalam penelitian ini menggunakan Regresi Linier
Berganda, Korelasi Linier, dan Uji Hipotesis menggunakan Uji F dan Unj t.

\section{HASIL DAN PEMBAHASAN}

\section{Anaslisis Regresi Linier Berganda}

Pengujian regresi linear berganda berguna untuk mengetahui pengaruh variabel independen (IQ,EQ,dan SQ) terhadap variabel dependen. Berdasarkan pengujian diperoleh hasil yang disajikan dalam tabel berikut.

Tabel 2. Hasil Perhitungan Linier Berganda

\begin{tabular}{|c|c|c|c|c|c|}
\hline \multirow{2}{*}{ Model } & \multicolumn{2}{|c|}{$\begin{array}{c}\text { Unstandardized } \\
\text { Coefficients }\end{array}$} & \multirow{2}{*}{$\begin{array}{c}\begin{array}{c}\text { Standardized } \\
\text { Coefficients }\end{array} \\
\text { Beta }\end{array}$} & \multirow{2}{*}{$\mathrm{t}$} & \multirow{2}{*}{ Sig. } \\
\hline & B & $\begin{array}{c}\text { Std. } \\
\text { Error }\end{array}$ & & & \\
\hline (Constant) & 28,131 & 8,434 & & 3,335 & ,002 \\
\hline IQ & 663 & 182 & ,542 & 3,652 & ,001 \\
\hline EQ & 133 & 104 & 198 & 1,278 & 212 \\
\hline SQ & 187 & 131 & 196 & 1,430 & 164 \\
\hline \multicolumn{6}{|c|}{ a. Dependent Variable: Pemahaman Akuntansi } \\
\hline
\end{tabular}

Sumber: Hasil Olah data SPSS 20

Berdasarkan hasil pada tabel diatas, dapat diperoleh persamaan regresi linier berganda sebagai berikut:

$Y=28,31+0,663 X_{1}+0,133 X_{2}+0,187 X_{3}+e$ Persamaan regresi diatas makna sebagai beriukut:

a. Konstanta 28,131 menunjukan besarnya pemahaman akuntansi pada saat kecerdasan intelektual, kecerdasan emosional, dan kecerdasan spiritual sama dengan nol.

b. b1 sebesar 0,663 artinya apabila variabel kecerdasan emosional dan kecerdasan spiritual sama dengan nol, maka Tabel 3 Hasil Perhit meningkatnya satu satuan variabel kecerdasan emosional akan meningkat pemahaman akuntansi sebesar 0,133.

c. b3 sebesar 0,187 artinya apabila variabel kecerdasan intelektual dan kecerdasan emosional sama dengan nol, maka meningkatnya satu satuan variabel kecerdasan spiritual akan meningkatkan pemahaman akuntansi sebesar 0187.

\section{Koefisien Korelasi Berganda}

Hasil pengelolaan dengan metode korelasi berganda terdapat pada tabel berikut : gan Koefisien Korelasi

\begin{tabular}{ccc}
\hline \multicolumn{3}{c}{ Model Summaryb } \\
\hline Model & $\mathrm{R}$ & R Square \\
\hline 1 &, $785 \mathrm{a}$ & 0,617 \\
\hline
\end{tabular}

a. Predictors: (Constant), SQ, EQ, IQ

b. Dependent Variable: Pemahaman Akuntansi

\section{Sumber: Hasil olahan SPSS 20}

Berdasarkan Tabel 3, menyatakan bahwa Koefisien Korelasi Berganda (R) variabel penelitian IQ (X1), EQ (X2), dan SQ (X3) secara bersama-sama terhadap Pemahaman Akuntansi $(\mathrm{Y})$ sebesar 0,785 yang berada pada interval nilai $\mathrm{R}(0,600 \quad$ - 0,7999) yang menunjukan hubungan yang kuat dan searah. Hal tersebut menunjukan bahwa IQ(X1),
EQ(X2), dan SQ (X3) yang baik akan mempengaruhi peningkatan Pemahaman Akuntansi(Y) kearah yang baik juga.

\section{Koefisien Determinasi (Uji R2)}

Koefisien Determinasi dilakukan untuk mengetahui besarnya persentase sumbangan pengaruh IQ (X1), EQ (X2), dan SQ 
(X3)terhadap Pemahaman Akuntansi(Y). Koefisien Determinasi diperoleh dengan cara mengkuadratkan hasil koefisien korelasi dan selanjutnya dikalikan $100 \%$ atau melihar $\mathrm{R}$ Square (R2) pada hasil SPSS. Berdasarkan Table 3 diatas, nilai $\mathrm{R}$ Square sebesar 0,617 atau $61,70 \%$. Hasil ini menunjukan bahwa variabel IQ (X1), EQ (X2), dan SQ (X3) mempengaruhi Pemahaman Akuntasni an dalam sajian tabel dibawah ini : sebesar $61,70 \%$ sedangkan sisanya $38,30 \%$ dipengaruhi oleh faktor lain yang tidak dianalisis dalam penelitian ini.

\section{Uji Hipotesis}

Uji F

Hipotesis 1 (H1) dalam penelitian ini diuju kebenarannya dengan menggunakan uji $\mathrm{F}$ yang terhadap

\begin{tabular}{lcc}
\multicolumn{3}{c}{ Tabel 4. Hasil Uji F } \\
\hline \multicolumn{3}{c}{ ANOVA $^{\text {a }}$} \\
\hline Model & $\mathrm{F}$ & Sig. \\
\hline 1 & 14,497 &, $000 \mathrm{~b}$
\end{tabular}

a. Dependent Variable: Pemahaman Akuntansi

b. Predictors: (Constant), Spiritual Quotient, Emotional Quotient, Intelegence Quotient Sumber :Hasil olahan SPSS 20

Hasil uji $\mathrm{F}$ diatas menunjukan bahwa variabel-varieabel IQ (X1), EQ (X2), dan SQ (X3) mempengangaruhi secara bersama-sama terhadap Pemahaman Akuntansi (Y) sebesar 14,497. Nilai Signifikansi 0,000 lebih kecil $(<)$ dari 0,05 yang mengartikan Ho1 di tolak dan Ha1 diterima.

Uji t

Hasil uji t dengan menggunaka program SPSS Windows versi 20 dapat dilihat sebagai berikut:

Tabel 5. Hasil uji t

\begin{tabular}{|c|c|c|c|}
\hline \multicolumn{2}{|c|}{ Model } & $\mathrm{T}$ & Sig. \\
\hline & (Constant) & 3,335 & ,002 \\
\hline & IQ & 3,652 & ,001 \\
\hline 1 & EQ & 1,278 & 212 \\
\hline & SQ & 1,430 & 164 \\
\hline
\end{tabular}

Sumber: Hasil Olahan SPSS 20

Berdasarkan tabel tersebut dapat diketahui besarnya pengaruh masing- masing variabel bebas terhadap variabel terikat sebagai berikut:

a. Pengujian koefisiensi regresi variabel intelegence Quotient (IQ)

Oleh karena $t_{\text {hitung }} \leq t_{\text {tabel }}(1,430 \leq 2,04227)$ dan nilai Sig. $0,001<0,05$, maka $\mathrm{H}_{0}$ ditolak. Dapat disimpulkan bahwa secara parsial Intellegense Quotien (IQ) berpengaruh terhdap pemahaman akuntansi.

b. Pengujian koefisien regresi variabel Emotional Quotient (EQ)

Oleh karena nilai $t_{\text {hitung }} \leq t_{\text {tabel }}$. $(1,278 \leq 2,04227)$ dan nilai Sig $0,212>0,05$, maka $\mathrm{h}_{0}$ diterima, dapat disimpulakan bahwa Emotional Quotient (EQ) tidak berpengaruh terhadap pemahaman akuntansi.

c. Pengujian koefisiensi regresi variabel Spiritual quotient
Oleh karena $t_{\text {hitung }} \leq t_{\text {tabel }}(1,430 \leq 2,04227)$ dan nilai Sig 0,164>0,05, maka $\mathrm{H}_{0}$ diterima. Disimpulkan bahwa secara parsial Spiritual Quotient (SQ) tidak berpengaruh terhadap pemahaman akuntansi.

\section{PEMBAHASAN}

\section{Pembahasan Hasil Uji F}

Berdasarkan pengolahan data, dapat disimpulakan terdapat pengaruh yang signifikan antara IQ,EQ,dan SQ terhadap pemahaman akuntansi, sehingga ketiga variabel tersebut secara simultan dapat meningkatkan pemahaman akuntansi. Oleh karnanya hipotesis mayor (H1) diterima. Hal tersebut mendukung penelitian Pasek (2015) berdasarkan hasil penelitiannya menyimpulkan bahwa secara simultan kecerdasan intelektual, kecerdasan emosional, dan kecerdasan spiritual mempengaruhi secara positif terhadap pemahaman akuntansi. 
2. Pembahasan hasil Uji Parsial (Uji t)

a. Pengaruh Intellegency Quotient (IQ) terhadap Pemahaman Akuntansi

Hasil uji regresi menunjukan variabel kecerdasan intelektual berpengaruh dan signifikan dengan koefisien regresi sebesar 0,633 . Hal ini berarti semakin banyak penerapan kecerdasan intelektual maka pemahaman akuntasni juga akan meningkat, karena kecerdasan intelektual merupakan kemampuan seseorang untuk memperoleh pengetahua, menguasai, dan menerapkan dalam menghadapi masalah yang dialamai pada siswa. Penelitian ini mendukung hasil penelitianoleh Raman (2014) yang

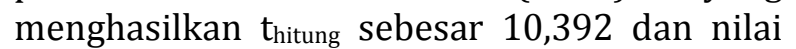
sig uji t sebesar 0,000, sedangkan didalam penelitian ini $t_{\text {hitung }}$ sebesar 3,652 dan nilai signikansi sebesar uji t sebesat 0,001 .

\section{b. Pengaruh Emotinal quotient terhadap Pemahaman Akuntansi}

(EQ)

Data yang diperoleh menunjkan bahwa EQ tidak berdampak terhdap pemahaman akuntansi yang ditunjukan dengan $t_{\text {hitung }}$ sebesar 1,278 $\leq t_{\text {tabel }} 2,04227$ dan probabilitas sebesar $0,212 \geq$ taraf signikan 0,05 . Data yang diperoleh tersebut tidak mendukung hasil penelitian yang telah dilakukan oleh Pasek (2015) yang menghasilkan EQ memiliki pengaruh yang positif dan signifikan terhdap pemahaman akuntansi. Seseorang dengan keterampilan emosional yang berkembang baik berarti kemungkinan besar ia akaan berhasil juga mengembangkan motivasinya untuk berprestasi. Oleh karnanya peneliti menduga EQ tidak berpengaruh secara langsung terhadap pemahaman akuntansi. Dalam hal ini EQ diduga sebagai variabel intervening.

\section{c. Pengaruh spiritual Quotient (SQ) terhadap Pemahaman Akuntansi}

Hasil yang diperoleh menunjukan SQ tidak mempengaruhi langsung terhdap pemahaman akuntansi. Hal tersebut ditujukan dengan $t_{\text {hitung }}$ sebesar 1,430 lebih kecil dari $t_{\text {tabel }}$ 2,042227 dan probabilitas sebesar 0,164 lebih besar dari taraf signikan. Hasil ini mendukung penelitian terdahulu Rahman (2014), yang menghasilkan thitung sebesar 0,544 dan nilai signifikansi sebsar 0,590 yang berarti tidak terdapat pengaryh antara variabel SQ terhadap pemahaman akuntansi. Kecerdasan spiritual mempengaruhi pemahaman akuntansi karena siswa yang mengandalkan hubungan dengann
ALLH SWT dalam pelajaran akan lebih mampu berfikir positif dan memiliki tujaun yang lebih baik. Peneliti menduga bahwa SQ sebagai variabel intervening, dengan kata lain SQ tidak berpengaruh secara langsung terhadap pemahaman akuntansi.

\section{Variabel yang Paling Dominan Berpengaruh Terhadap Pemahaman Akuntansi}

Berdasarkan pengelolaan data yang memberikan pengaruh paling dominan kepada pemahaman akuntansi ialah variabel Intellegency Quotient (IQ) dengan probabilitas sebesar $0,001 \leq$ taraf signifikan sebesar 0,05. Variabel Emotional Quotient (EQ) dan Spiritual Quotien (SQ) tidak berpengaruh, karena memiliki probabilitas sebesar 0,212 dan 0,164. Artinya bahwa tingka IQ yang dimiliki oleh para siswa mendominasi atau memicu dalam meningkatkan pehamannya terhadap akuntansi.

\section{KESIMPULAN}

Berdasarkan pengolahan dan analisi data, serta hasil penelitian dan pembahasan, maka kesimpulan yang didapat dalam penelitian ini adalah sebagai berikut :

1. Siswa-siswi jurusan Akuntansi Kelas XII di SMK Sumpah Pemuda 2 memiliki rata-rata IQ dengan nilai rata-rata yang dapat dikategorikan sangat baik. Adapun nilai rata-rata EQ yang dapat dikategorikan sangat baik, sedangkan nilai rata-rata SQ berdasarkan penilaian dapat dinyatakan baik. Pemahaman Akuntansi mempunyai nilai rata-rata yang dinyatakan bahwa variabel pemahaman akuntansi sangat kompeten. Intellegence Quotien (IQ), Emotional Quotient (EQ), dan Siritual Quotient (SQ),secara simultan berpengaruh signifikan terhadap Pemahaman Akuntansi di SMK Sumpah Pemuda 2.

2. Secara parsial yang mepengaruhi secara positif dan signifikan adalah Intellegence Quotient (IQ), sedangkan Emotional Quotien (EQ) dan Spiritual Quotient (SQ) tidak berpengaruh terhadap Pemahaman Akuntansi.

3. Variabel yang mempengaruhi secara dominan atau lebih besar dari variabel lain yang diteliti terhadap Pemahaman Akuntansi adalah Intellegence Quotient (IQ). 


\section{DAFTAR PUSTAKA}

Ardana. 2013 "kecerdasan Intelektual, kecerdasan emosional, kecerdasan Spiritual, dan Kesehatan Fisik untuk Memprediksi Prestasi Belajar Mahasiswa Akuntansi". E-Journal Fakultas Ekonomi Universitas Taarumanegara Vol. XVII No.3

Artana, Made Buda. 2014. "Pengaruh Kecerdasan Emosional, Kecerdasan Spiritual, dan Pemahaman Belajar terhadap Pemahaman Akuntansi". EJournal S1 AK Universitas Pendidikan Sansha Volume: 2 No. 1.

Baridwan, Zaaki. 2004. Intermadite Accountin. Yogyakarta : BPFE.

Belkaoli, Ahmed Raihi. 2000. Teori Akuntansi. Buku I. Jakarta: Salemba Empat.

Cooper, Donald R. \& Pamela S. Schhinder. 2007 Metode Riset Bisnis (Vol. 2 edisi 9). Jakarta: PT. Media Global Edukasi.

Dwijayanti, A. P. 2009. Pengaruh Kecerdasan Emosional, Kecerdasan Intelektual, Kecerdasan Spritual, dan Kecerdasan Sosial terhadap Pemahaman Akuntansi. Skripsi Universitas Pembangunan Nasional "Veteran". Jakarta.

Ghozali, Imam, 2006, Aplikasi Analisis Multivariate Dengan program SPSS (Edisi Kedua), Badan Penerbit Universitas Diponegoro, Semarang.

Golman, D. 2005. Kecerdasan Emosi untuk Mencapai Puncak Prestasi. Edisi Keenam. Jakarta: PT. Gramedia Putaka Utama.

Harahap, Alwi Syaffuddin. 2010. Menajemen Sumber Daya Manusia: Strategi Keunggulan Kompetitif. Yogyakrta; BPFE.

Hariyoga, Septian dan Suprianto, Edy. 2011. "pengaruh Kecerdasan Emociona, Perilaku Pelajar, dan Budaya terhadap Tingkat Pemahaman Akuntansi dengan kepercayaan Diri sebagai Manajemen: Konsep dan Pengembangan. Bandung: Lingga Jaya.
Variabel Pemoderasi" Simposium Nasional Ankuntansi XIV.

Ikatan Akuntansi Indonesia.2012 Standar Akuntansi Keuangan. PSAK. Cetakan Keempat. Buku Satu. Jakarta: Salemba Empat.

Lubis, Arfan, Ikhsan. 2010. Akuntansi keperilakuan. Edisi 2. Salemba 4. Jakarta.

Marchel V.J. veenman, Pascal Wilhelm, Jos J. Beishuizen. 2004. "The Relation Between Intellectual and Metacognitive Skills from a Developmental Perpectuve". Jurnal learning and Instruction, No13,89-109.

Mardahelena. 2007. "pengaruh kecerdasan Emosional (Pengenalan Diri, Pengendalian Diri, Motivasi, Empati dan Keterampilan Sosial) Terhadah Tingkat Pemahaman Matakuliah Akuntansi."

Mawardi. M.Cholid. 2011. "Tingkat Pemahaman Mahasiswa Akuntansi Terhadap Konsep Dasar Akuntansi di Perguruan Tinggi di Kota Malang'. Jurnal Akuntansi Fakultas Ekonomi Universitas Islma (UNISMA) Malang.

Panagian, Reza. 2012. “ Pengaruh Kecerdasan Emosional dan Kecerdasan Sipritual Terhadap Pemahaman Akuntansi pada Pendidikan Akuntansi". Artikel Ilmiah tidak di Publikasikan: Sekolah Tinggi Ilmu Ekonomi Perbanas.

Rachmi, Fillia. 2010. "Pengaruh Kecerdasan Emosinaln, Kecerdasan Spiritual, dan Perilaku Belajar Terhadap Pemahaman Akuntansi". Semarang. Jurnal Pendidikan Akuntansi.

Robbins, S. P., \& Judge, T. A. 2008. Organizational behavior 13th Edition. US: Prentice Hall.

Sugiyono, Azhar. 2004. Sistem Informasi

Zohar, D., dan Marshall, I. 2007. SQ: Memanfaatkan Kecerdasan Spiritual dalam Berfikir Intergralistik dan 
Holistik untuk Memaknai Kehidupan.

Diterjemahkan oleh Rahmi Astuti, 